\title{
RNAi-mediated knockdown of cyclooxygenase2 inhibits the growth, invasion and migration of SaOS2 human osteosarcoma cells: a case control study
}

Qinghua Zhao ${ }^{1}$, Chuan Wang ${ }^{2}$, Jiaxue Zhu', Lei Wang ${ }^{1}$, Shuanghai Dong ${ }^{1}$, Guoqiao Zhang², Jiwei Tian ${ }^{\text {* }}$

\begin{abstract}
Background: Cyclooxygenase2 (COX-2), one isoform of cyclooxygenase proinflammatory enzymes, is responsible for tumor development, invasion and metastasis. Due to its role and frequent overexpression in a variety of human malignancies, including osteosarcoma, COX-2 has received considerable attention. However, the function of COX-2 in the pathogenesis of cancer is not well understood. We examined the role of COX-2 in osteosarcoma.

Methods: We employed lentivirus mediated-RNA interference technology to knockdown endogenous gene COX-2 expression in human osteosarcoma cells (SaOS2) and analyzed the phenotypical changes. The effect of COX-2 treatment on the proliferation, cell cycle, invasion and migration of the SaOS2 cells were assessed using the MTT, flow cytometry, invasion and migration assays, respectively. COX-2, vascular endothelial growth factor (VEGF), epidermal growth factor (EGF), basic fibroblast growth factor (bFGF) mRNA and protein expression were detected by RT-PCR and western blotting.
\end{abstract}

Results: Our results indicate that a decrease of COX-2 expression in human osteosarcoma cells significantly inhibited the growth, decreased the invasion and migration ability of SaOS2 cells. In addition, it also reduced VEGF, EGF and bFGF mRNA and protein expression.

Conclusions: The COX-2 signaling pathway may provide a novel therapeutic target for the treatment of human osteosarcoma.

\section{Background}

Osteosarcoma is the most common primary malignant tumor arising in bone predominantly affecting children and adolescents [1]. It is also one of the most heterogeneous of human tumors [2]. The 5-year survival rate has increased up to $70 \%$ in patients with localized disease, however, the prognosis is very poor and the 5-year survival rate is only $20-30 \%$ in patients with metastatic disease at diagnosis [3]. Although an adjuvant treatment regimen after surgical resection seems to prolong survi$\mathrm{val}$, the precise treatment protocol of drug-of-choice is still debated because the exact mechanisms the

\footnotetext{
* Correspondence: tjw609@163.com

'Department of Orthopaedics, Affiliated First People's Hospital, Shanghai Jiao

Tong University, 100 Haining Road, Shanghai 200080, China

Full list of author information is available at the end of the article
}

development and progression of osteosarcoma are still largely unknown [4]. Effective systemic therapy capable of reversing the aggressive nature of this disease is currently not available [5]. Therefore, an understanding of the molecular mechanisms of osteosarcoma is one of the most important issues for treatment. New therapeutic strategies are necessary to increase survival rates in patients with osteosarcoma.

Cyclooxygenases are key enzymes in the conversion of arachidonic acid into prostaglandin (PG) and other eicosanoids including PGD2, PGE2, PGF2, PGI2 and thromboxane A2 [6]. There are two isoforms of cyclooxygenase, designated COX-1 and COX-2. COX-1 is constitutively expressed in most tissues, and seems to perform physiological functions [7]. However, COX-2 is an inducible enzyme associated with inflammatory

\section{() Biomed Central}

(c) 2011 Zhao et al; licensee BioMed Central Ltd. This is an Open Access article distributed under the terms of the Creative Commons Attribution License (http://creativecommons.org/licenses/by/2.0), which permits unrestricted use, distribution, and reproduction in any medium, provided the original work is properly cited. 
disease and cancer. Many reports have indicated that COX-2 expression is increased in a variety of human malignancies, including osteosarcoma, and is responsible for producing large amounts of PGE2 in tumor tissues [8-11]. These molecules are thought to play a critical role in tumor growth, because they reduce apoptotic cell death, stimulate angiogenesis and invasiveness $[12,13]$. COX-2 overexpression has been associated with poor prognosis in osteosarcoma [14]. Selective COX-2 inhibitors have been shown to significantly reduce the cell proliferation rates as well as invasiveness in U2OS cells [15]. Transgenic mice overexpressing human COX-2 in mammary glands developed focal mammary gland hyperplasia, dysplasia and metastatic tumors [16]. Epidemiological studies have revealed a decreased risk of colon cancer in people who regularly take COX-2 inhibitors $[17,18]$. Specifically, COX-2 silencing mediated by RNA interference (RNAi) has been found to be associated with decreased invasion in laryngeal carcinoma [19] and human colon carcinoma. In this report, for the first time, we employed RNAi technology to explore the therapeutic potential of the DNA vectorbased shRNA targeting COX-2 for the treatment of human osteosarcoma. Moreover, the mechanism underlying inhibition of angiogenesis and metastasis by targeting COX-2 is not fully understood. Another aim of this study was to establish whether there is a direct relationship between COX-2 expression and VEGF, EGF and bFGF production in osteosarcoma cells.

\section{Methods}

\section{Cell culture and infection}

The human osteosarcoma cell line, SaOS2 and 293T cells were purchased from the American Type Culture Collection. Cells were grown in 5\% CO2 saturated humidity, at $37^{\circ} \mathrm{C}$ and cultured in DMEM (Gibco, USA) supplemented with penicillin/streptomycin, $2 \mathrm{mmol} / \mathrm{L}$ glutamine and 10\% FBS. Cells were subcultured at $9 \times$ $10^{4}$ cells per well into 6-well tissue culture plates. After $24 \mathrm{~h}$ culture, cells were infected with recombinant lentivirus vectors at a multiplicity of infection (MOI) of 40 .

\section{Design of shRNA and plasmid preparation}

We designed and cloned a shRNA template into a lentivirus vector previously used [5]. A third generation selfinactivating lentivirus vector pGCL-GFP containing a CMV-driven GFP reporter and a U6 promoter upstream of the cloning sites. Three coding regions corresponding to targeting human COX-2 (GenBank Accession: NM 000963.2) were selected as siRNA target sequences (Table 1) under the guide of siRNA designing software offered by Genscript. We constructed three shRNA-COX-2 lentivirus vectors, namely LV-COX-2siRNA-1, LV-COX2siRNA-2 and LV-COX-2siRNA-3, respectively. To detect the interference effects of different target, COX-2 mRNA and protein levels were determined using RT-PCR and western blotting. Recombinant lentivirus vectors and control lentivirus vector were produced by co-transfecting with the lentivirus expression plasmid and packaging plasmids in $293 \mathrm{~T}$ cells. Infectious lentiviruses were harvested $48 \mathrm{~h}$ posttransfection, centrifuged and filtered through 0.45 um cellulose acetate filters. The infectious titer was determined by hole-by-dilution titer assay. The virus titers produced were approximately $10^{9}$ transducing $\mathrm{u} / \mathrm{ml}$ medium.

\section{Cell proliferation assay}

Cell proliferation was determined by 3-(4,5-dimethylthiazole-2-yl)-2,5-diphenyltetrazolium bromide (MTT) assay. SaOS2 cells were seeded in 96-well culture plates in culture medium at an optimal density $\left(4 \times 10^{3}\right.$ cells per well) in triplicate wells for the parental, LV-Control and LV-COX-2siRNA cells. After 1, 2, 3, 4 and 5 d, cells were stained with $20 \mathrm{ml}$ MTT $(5 \mathrm{mg} / \mathrm{ml}$ ) (Sigma, St Louis, $\mathrm{MO}, \mathrm{USA}$ ) at $37^{\circ} \mathrm{C}$ for $4 \mathrm{~h}$ and subsequently made soluble in $150 \mathrm{ml}$ of DMSO. Absorbance was measured at $490 \mathrm{~nm}$ using a microtiter plate reader. Cell growth curves were calculated as mean values of triplicates per group.

\section{Flow cytometry}

Cells were collected and washed with PBS, then centrifuged at $800 \mathrm{r} / \mathrm{min}$ and fixed with $70 \%$ cold ethanol kept at $4^{\circ} \mathrm{C}$ overnight. Cells were permeabilized in reagent consisting of $0.5 \%$ Triton $\mathrm{X}-100,230 \mu \mathrm{g} / \mathrm{ml}$ RNase A and $50 \mu \mathrm{g} / \mathrm{ml}$ propidium iodide in PBS. Samples were kept at $37^{\circ} \mathrm{C}$ for $30 \mathrm{~min}$, followed by flow cytometry analysis (Becton Dickinson FACScan).

\section{Real-time PCR}

Total RNA was extracted from cultured cells using Trizol reagent (Invitrogen, USA) for reverse transcription. RNA were synthesized to cDNA using Superscript First-Strand Synthesis Kit (Promega, USA) following the manufacturer's protocols. Quantitative real-time polymerase chain reaction (RT-PCR) assays were carried out using SYBR Green Real-Time PCR Master Mix (Toyobo, Osaka, Japan) and RT-PCR amplification equipment using specific primers: COX-2, sense strand 5'CCCTTGGGTGTCAAAGGTAAA-3', antisense strand 5'-AAACTGATGCGTGAAGTGCTG-3', COX-1, sense strand 5'-ATGCCACGCTCTGGCTACGTG-3', antisense strand 5'-CTGGGAGCCCACCTTGAAGGAGT3', $\beta$-actin, sense strand 5'-GCGAGCACAGAGCCTCG CCTTTG-3', antisense strand 5'-GATGCCGTGCTCGATGGGGTAC-3', VEGFA sense strand 5'-CGTGTAC GTTGGTGCCCGCT-3', antisense strand 5'-TCCTT CCTCCTGCCCGGCTC-3', VEGFB sense strand 5'CCCAGCTGCGTGACTGTGCA-3', antisense strand 
Table 1 Interfering sequence specified for COX-2 gene

\begin{tabular}{|c|c|}
\hline & Sequence \\
\hline \multirow[t]{2}{*}{ LV-COX-2siRNA-1 } & $\begin{array}{l}\text { Oligo 1: 5'TaaACACAGTGCACTACATACTTAtcaagagTAAGTATGTAGTG } \\
\text { CACTGTGTIIIIIIC3' }\end{array}$ \\
\hline & $\begin{array}{l}\text { Oligo2: 5'TCGAGAAAAAAaaACACAGTGCACTACATACTTActcttgaTAA } \\
\text { GTATGTAGTGCACTGTGTTTA3' }\end{array}$ \\
\hline \multirow[t]{2}{*}{ LV- COX-2siRNA-2 } & $\begin{array}{l}\text { Oligo1: 5'TaaTCACATTTGATTGACAGTCCAtcaagagTGGACTGTCAATC } \\
\text { AAATGTGA TTITIITC3' }\end{array}$ \\
\hline & $\begin{array}{l}\text { Oligo2: 5'TCGAGAAAAAAaaTCACATTTGATTGACAGTCCActcttgaTGG } \\
\text { ACTGTCAATCAAATGTGATTA3' }\end{array}$ \\
\hline \multirow[t]{2}{*}{ LV- COX-2siRNA-3 } & $\begin{array}{l}\text { Oligo1: 5'TaaCCTTCTCTAACCTCTCCTATTtcaagagAATAGGAGAGGTT } \\
\text { AGAGAAGGTTITITTC3' }\end{array}$ \\
\hline & $\begin{array}{l}\text { Oligo2: 5'TCGAGAAAAAAaaCCTTCTCTAACCTCTCCTATTctcttgaAAT } \\
\text { AGGAGAGGTTAGAGAAGGTTA3' }\end{array}$ \\
\hline
\end{tabular}

The three interfering sequence targeted for human COX-2 gene were named LV-COX-2siRNA-1, LV-COX-2siRNA-2 and LV-COX-2siRNA-3, whose coding regions were corresponding to directly at human COX-2 (NM 000963.2) starting at 352, 456 and 517, respectively.

5'-TCAGCTGGGGAGGGTGCTCC-3', VEGFC sense strand 5'-TGTTCTCTGCTCGCCGCTGC-3', antisense strand 5'-TGCATAAGCCGTGGCCTCGC-3', EGF sense strand 5'-TGCTCCTGTGGGATGCAGCA-3', antisense strand 5'-GGGGGTGGAGTAGAGTCAAGACAGT-3', bFGF sense strand 5'-CCCCAGAAAACCC GAGCGAGT-3', antisense strand 5'-GGGCACCGC GTCCGCTAATC-3', The expression of interest genes were determined by normalization of the threshold cycle (Ct) of these genes to that of the control $\beta$-actin.

\section{Western blotting}

Cells were lysed in RIPA buffer (150 mM NaCl, $100 \mathrm{mM}$ Tris- $\mathrm{HCl}, 1 \%$ Tween-20, 1\% sodium deoxycholate and $0.1 \%$ SDS) with $0.5 \mathrm{mM}$ EDTA, $1 \mathrm{mM}$ PMSF, $10 \mu \mathrm{g} / \mathrm{ml}$ aprotinin and $1 \mu \mathrm{g} / \mathrm{ml}$ pepstatin. Proteins were resolved in SDS-PAGE and transferred to PVDF membranes, which were probed with appropriate antibodies, The immunoreactive protein complexes were detected by enhanced chemiluminescence (Amersham Bioscience, Boston, MA). The specific antibody used: anti-COX-2 antibody (Cell Signaling, \#4842, $1 \mu \mathrm{g} / \mathrm{ml}$ ), anti-VEGFA antibody (Abcam, ab51745, $0.1 \mu \mathrm{g} / \mathrm{ml}$ ), anti-VEGFB antibody (Cell Signaling, \#2463, $1 \mu \mathrm{g} / \mathrm{ml}$ ), anti-VEGFC antibody (Cell Signaling, \#2445, $1 \mu \mathrm{g} / \mathrm{ml}$ ), anti-EGF antibody (Cell Signaling, \#2963, $1 \mu \mathrm{g} / \mathrm{ml}$ ), anti-bFGF antibody (Cell Signaling, \#8910, $1 \mu \mathrm{g} / \mathrm{ml}$ ), anti- $\beta$-actin antibody (Cell Signaling, \#4970, $1 \mu \mathrm{g} / \mathrm{ml}$ ).

\section{Invasion assay}

Invasion by $\mathrm{SaOS} 2$ cells was assayed using 12 -well cell culture chambers containing inserts with $8 \mu \mathrm{m}$ pores coated with matrigel (Corning, USA). The cells were added to the upper chamber at a density of $4 \times 10^{4}$ cells/insert, After $24 \mathrm{~h}$ of incubation, cells on the upper surface were wiped off with a cotton swab. Cells that had invaded the lower surface were fixed with $70 \%$ ethanol, stained with $0.2 \%$ crystal violet, Invasiveness was quantitated by selecting ten different views (100 times) and calculating the number of invading cells.

\section{Migration assay}

Migration assays were performed using two-chamberTranswell (Corning, USA) as described previously [20]. The lower surface of a polycarbonate filter with $8 \mu \mathrm{m}$ pores was coated with $1 \mu \mathrm{g} / \mathrm{ml}$ bovine collagen IV. Cells were trypsinized and suspended in a serum-free medium containing $1 \% \mathrm{BSA}$ at a concentration of $4 \times 10^{4}$ cells/ insert. The cells were placed in the upper chamber and free DMEM was placed in the lower chamber. After $12 \mathrm{hr}$ at $37^{\circ} \mathrm{C}$, the cells in the upper chamber were wiped off with a cotton swab. The cells on the lower surface of the filter were fixed with $70 \%$ ethanol, stained with $0.2 \%$ crystal violet, migration was quantitated by selecting ten different views (100 times) and calculating the number of migrated cells.

\section{Statistical analysis}

All statistical analyses were performed using SPSS 10.0. Data were expressed as mean \pm SD. The statistical correlation of data between groups was analyzed by oneway analysis of variance (ANOVA) and Student's t test, where $P<0.05$ were considered significant.

\section{Results}

Selection of the most effective COX-2 specific shRNA expression vector

To exclude off-target silencing effects mediated by specific shRNA, we employed three different COX-2 shRNAs (shRNA1, shRNA2, shRNA3). Three specific plasmids and the control plasmid were cotransfected with packing plasmid into $293 \mathrm{~T}$ cells, respectively. $48 \mathrm{~h}$ after transfection, GFP expression in 293T cells was observed under a fluorescent microscope (Figure 1a). 
The level of COX-2 expression was evaluated by RT-PCR and western blotting. Results indicated that all of the COX-2shRNA-1, shRNA-2 and shRNA-3 significantly decreased the COX-2 mRNA and protein levels in 293T cells. According to the results, LV-COX-2siRNA-1 was the most effective lentivirus vector, and was used in the following experiments (Figure $1 \mathrm{~b}$ and $1 \mathrm{c}$ ).

\section{Downregulation of COX-2 expression by LV-COX-2siRNA-1} in SaOS2 cells

To explore the effect of LV-COX-2siRNA-1 on the expression of COX-2, GFP expression was observed under a fluorescent microscope in SaOS2 cells $72 \mathrm{~h}$ after infection with LV-COX-2siRNA-1 (Figure 2a). RT-PCR was employed to test the mRNA levels of COX-2 in parental, LV-Control and LV-COX-2siRNA-1 cells. The results indicated that $\mathrm{LV}-\mathrm{COX}-2$ siRNA-1 significantly inhibited mRNA $(P=0.0001)$ and protein (data not shown) levels of COX-2 compared with the LV-Control and parental SaOS2 cells (Figure $2 \mathrm{~b}$ ). We also found that
LV-COX-2siRNA-1 did not affect the COX1 mRNA level in $\mathrm{SaOS} 2$ cells compared with the LV-Control and parental SaOS2 cells (Figure 2c), which indicated the efficacy and specificity of LV-COX-2siRNA-1.

Effects of LV-COX-2siRNA-1 on cell growth of SaOS2 cells To determine the effects of LV-COX-2siRNA-1 on cell proliferation, MTT assays were performed to examine the cell proliferation activity. Cell proliferation was monitored for five days after SaOS2 cells were infected with LV-COX-2siRNA-1 or LV-Control. As shown in Figure $3 \mathrm{a}$, the growth of cells infected with LV-COX2siRNA-1 was significantly inhibited compared with LVControl and parental SaOS2 cells.

\section{Effects of LV-COX-2siRNA-1 on cell cycle of SaOS2 cells} The effects of LV-COX-2siRNA-1 on the cell cycle of SaOS2 cells were examined and each experiment was performed in triplicate. SaOS2 cells were infected with LV-COX-2siRNA-1; $72 \mathrm{~h}$ after cell proliferation, G1, G2

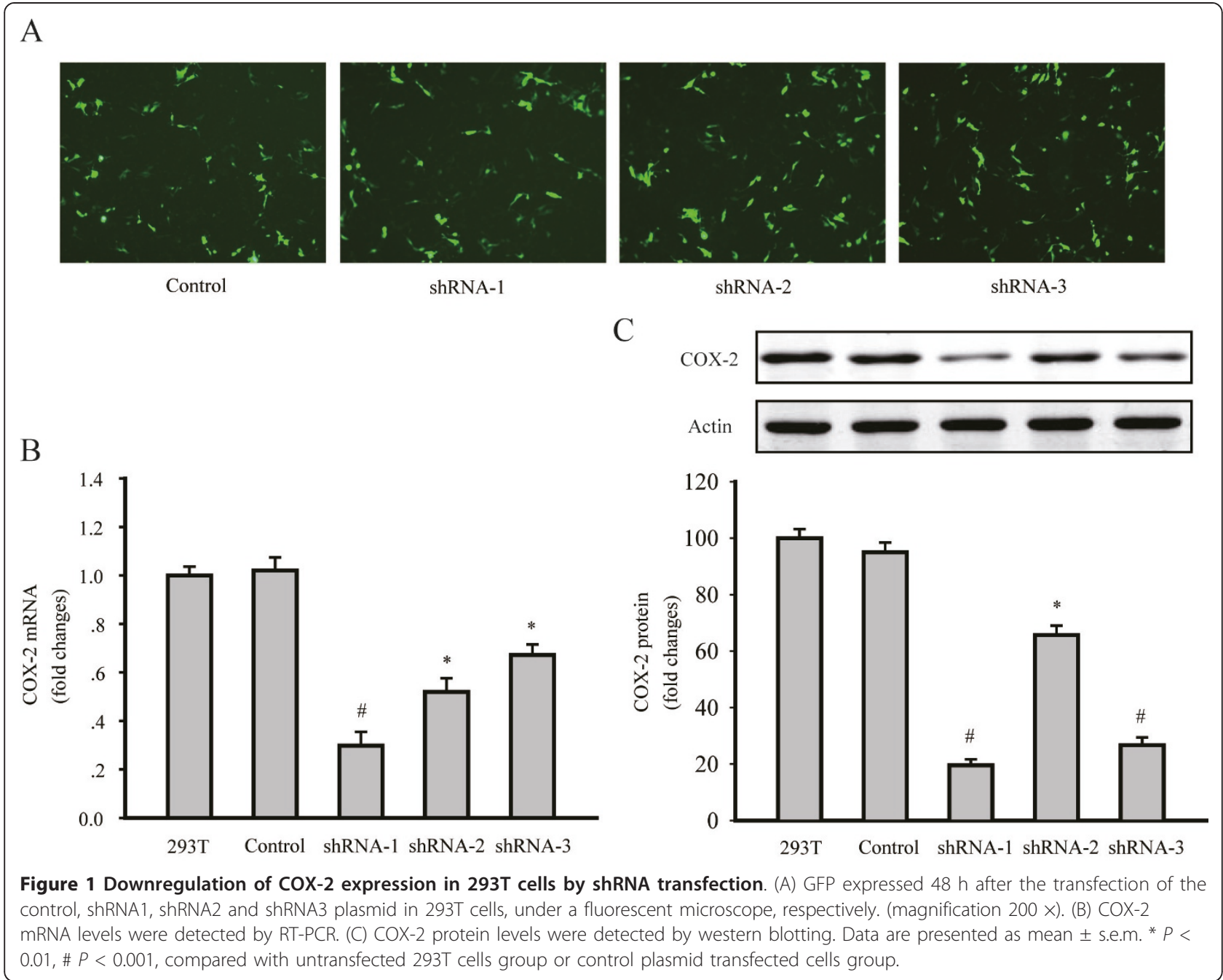




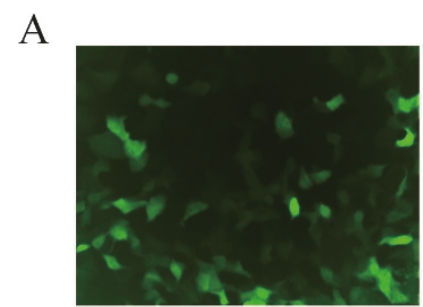

LV-control

$\mathrm{B}$

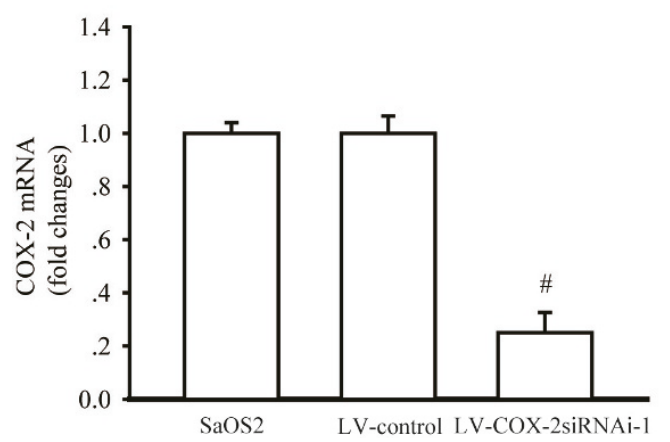

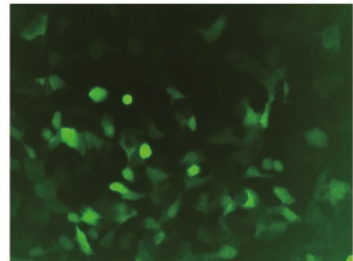

LV-COX-2siRNAi-1

$\mathrm{C}$

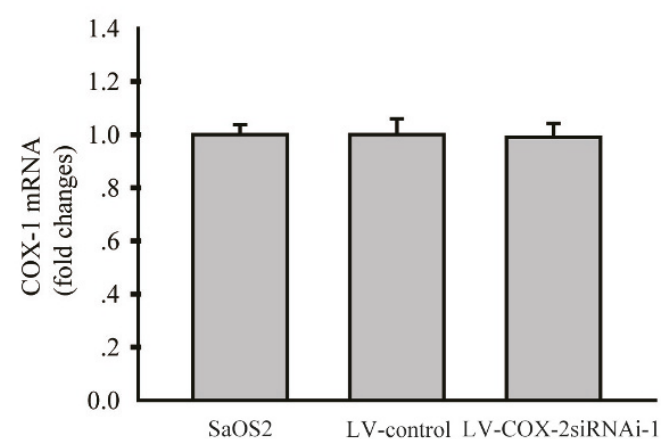

Figure 2 COX-2 expression was inhibited by LV-COX-2siRNAi-1 in SaOS2 cells. (A) SaOS2 cells infected with LV-Control and LV-COX2siRNAi-1. GFP expressed $48 \mathrm{~h}$ after the infection (magnification $40 \times$ ). COX-2 (B), but not COX-1 (C) mRNA level was significantly inhibited by LV-COX-2siRNAi-1. Data are presented as mean \pm s.e.m. \# $P<0.001$, compared with LV-Control and parental SaOS2 cell group.

and $\mathrm{S}$ phase of cells were detected by flow cytometric analysis. The percentage of SaOS2 cells infected with LV-COX-2siRNA-1 in the G1 phase significantly increased, while the percentage in the G2 phase notably decreased compared with LV-Control and parental SaOS2 cells. This indicates that RNAi-mediated downregulation of COX-2 expression in SaOS2 cells leads to cell cycle arrest in the G1 phase (Table 2).

\section{Effects of LV-COX-2siRNA-1 on invasion and migration ability of SaOS2 cells}

Matrix invasion and migration abilities of cancer cells are associated closely with metastatic potential. The in vitro cell invasion and migration assay were performed and the number of invading and migrating cells were counted. Invasion and migration activity of SaOS2 cells were assessed in the various transfectants.

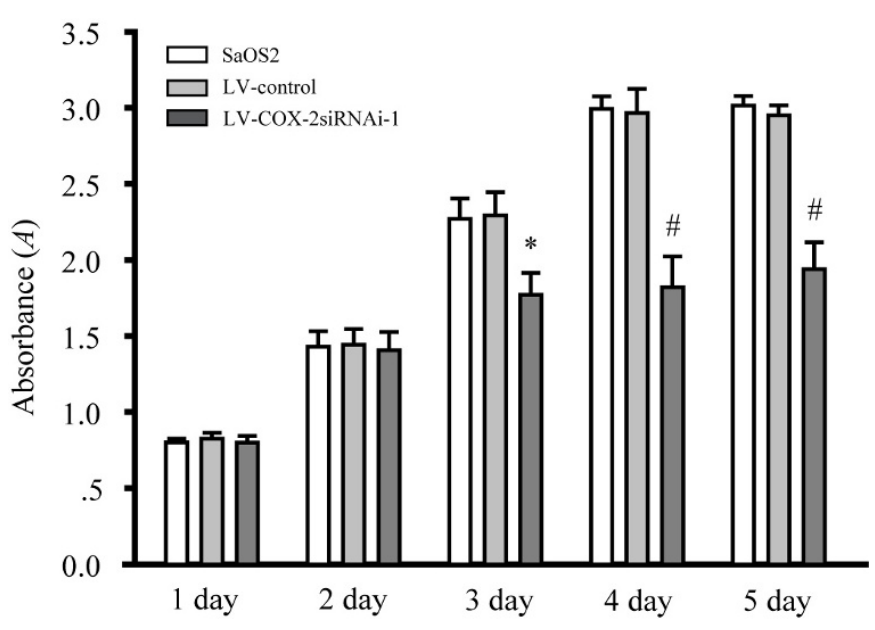

Figure 3 Osteosarcoma cells proliferation were assessed by MTT assays. The growth of SaOS2 cells in 96-well plates applied to absorbance at $490 \mathrm{~nm}$ were detected on day 1, 2, 3, 4 and 5, respectively. Data are presented as mean \pm s.e.m. \# $P<0.001$, compared with LV-Control and parental SaOS2 cell group. 
Table 2 Cell cycle detected by flow cytometry (\%)

\begin{tabular}{llll}
\hline Group & G1 fraction & G2 fraction & S fraction \\
\hline SaOS-2 & $48.52 \pm 1.38$ & $36.40 \pm 1.12$ & $18.0 \pm 2.08$ \\
LV-Control & $46.46 \pm 1.56$ & $36.42 \pm 1.51$ & $17.12 \pm 1.78$ \\
LV-siRNA-1 & $58.79 \pm 1.54^{\mathrm{a}}$ & $25.09 \pm 1.16^{\mathrm{b}}$ & $16.12 \pm 2.16$ \\
\hline
\end{tabular}

Cell cycle was detected by flow cytometry. The G1 phase fraction of the LVCOX-2siRNAi-1 cells was markedly increased compared with the LV-control and parental SaOS2 cells. ${ }^{a} P<0.01$ compared with LV-control cells. Conversly, The G2 phase fraction of the LV-COX-2siRNAi-1 cells was notably decreased compared with the LV-control and parental SaOS2 cells. ${ }^{\mathrm{b}} P<0.001$ compared with the LV-control and parental SaOS2 cells.

As shown in Figure 4a, b and 4c, COX-2 cells infected with LV-COX-2siRNA-1 showed much lower invasion and migration activities compared with the LV-Control and parental SaOS2 cells, which suggested that the knockdown of COX-2 has a direct inhibitory effect on invasion and migration rates of SaOS2 cells.

\section{Effects of LV-COX-2siRNA-1 on VEGF, EGF and bFGF expression in SaOS2 cells}

To further elucidate the mechanism of LV-COX-2siRNA1-mediated downregulation of invasion and migration, the expression of genes associated with angiogenesis were examined. The mRNA levels of vegf, egf and $b f g f$ of SaOS2 cells infected with LV-COX-2siRNA-1 were analyzed by RT-PCR (Figure 5a). Results revealed that the vegfa, egf and $b f g f$ levels were decreased in SaOS2 cells infected with LV-COX-2siRNA-1 compared with the LV-Control and parental SaOS2 cells. Protein expression was evaluated by western blotting (Figure $5 \mathrm{~b}$ and $5 \mathrm{c}$ ). Silencing of COX-2 expression by transfection of LV-COX-2siRNA-1 significantly decreased the expression of VEGFA $(P=0.0001)$, EGF $(P<0.0001)$ and bFGF $(P=0.02)$ compared with the LV-Control and SaOS2 cells, while levels of VEGFB and VEGFC had no significant changes.

A SaOS-2 LV-Control LV-COX-2siRNA-1
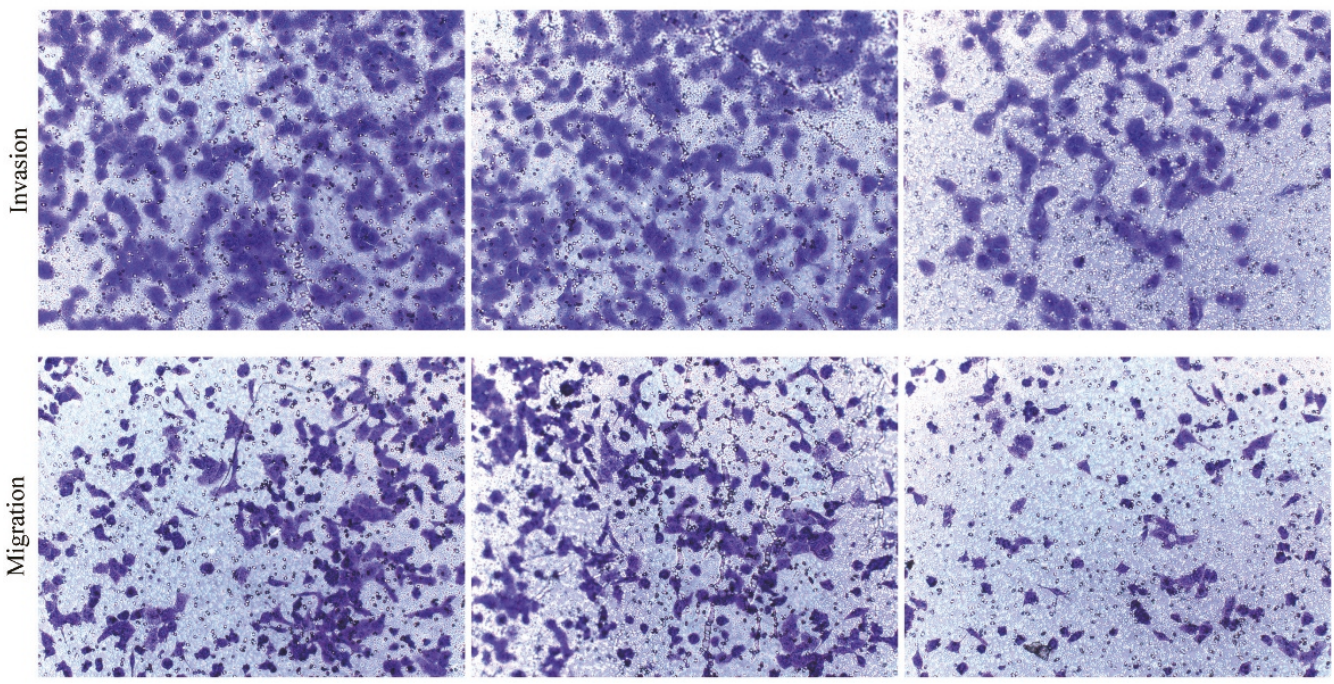

B

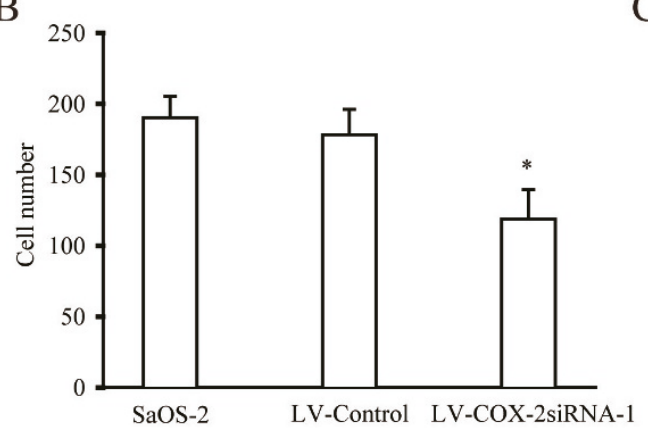

$\mathrm{C}$

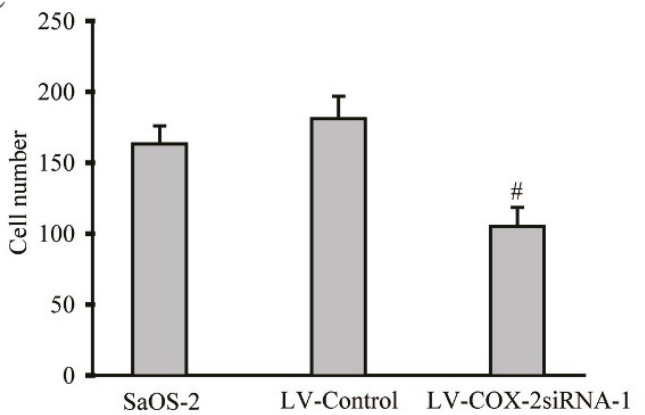

Figure 4 Measurement of invasion and migration of SaOS2 cells. (A) Invading and migrating cells were stained with $0.2 \%$ crystal violet and visualized by microscopy. (magnification $100 \times$ ). (B) Invasion and migration assay indicated LV-COX-2siRNA-1 significantly decreased the invasion or migration ability of the SaOS2 cells. Data are presented as mean \pm s.e.m. \# $P<0.001$, compared with LV-Control and parental SaOS2 cell group. 


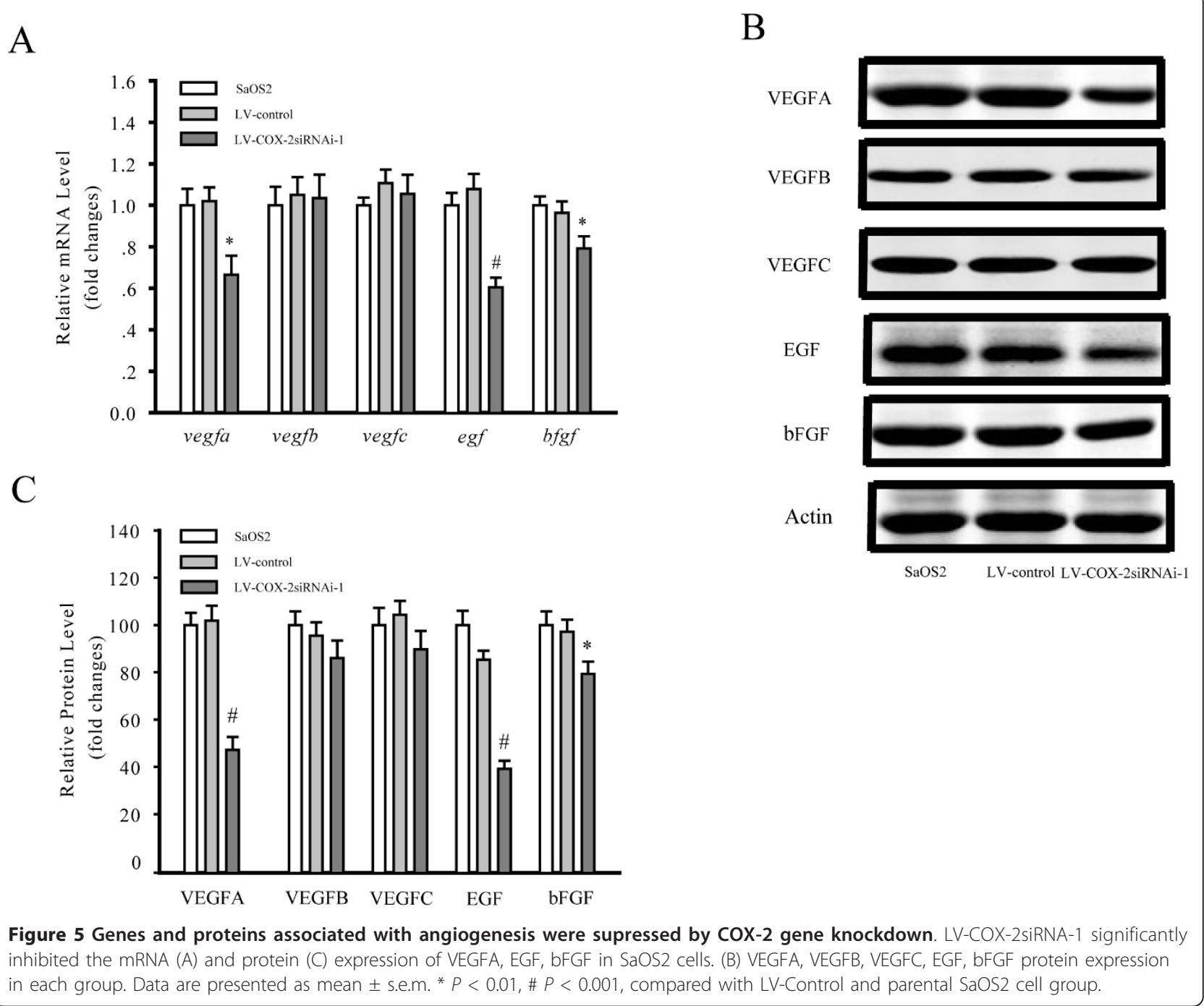

\section{Discussion}

Many reports have indicated that COX-2 is overexpressed in a variety of human malignancies and is responsible for producing a large quantity of PGE2 in tumor tissues [21-23]. PGE2 stimulates angiogenesis, promotes cell proliferation and invasiveness, and thus it plays a critical role in tumor growth $[24,25]$. In addition, $\mathrm{COX}-2$ expression has been found significantly higher in tumors of higher grade and in more aggressive malignancies [26]. Many policies have been employed to inhibit COX-2 expression and function. Dandekar et al pointed out that reduction of COX-2 suppresses tumor growth and improves efficacy of chemotherapeutic drugs in prostate cancer [27-29]. Other groups reported that the COX-2 inhibitors attenuate migration and invasion of breast cancer cells [30]. These data indicate that, as a critical regulator of proliferation of tumor cells, COX-2 is a considerable target for inhibiting growth, triggering apoptosis, and reducing invasion activity.
To this day, there have been many strategies used to inhibit COX-2 expression and activity, including inhibitors and antisense oligonucleotides and RNAi $[27,29,30]$. Selective COX-2 inhibitors both inhibit tumor cell growth and boost chemosensitivity or radiosensitivity of malignancies [31,32]. To ensure the efficacy and specificity of COX-2 as a therapeutic target, we employed RNAi technology. RNAi refers to the introduction of homologous double stranded RNA (dsRNA) to specifically target a gene's product, resulting in null or hypomorphic phenotypes $[33,34]$. It has demonstrated great prospects for studying gene function, signal transduction research and gene therapy. We used RT-PCR and western blotting to proof the efficacy of LV-COX-2siRNA-1 on COX-2 expression in $293 \mathrm{~T}$ and SaOS2 cells. LVCOX-2siRNA-1 was applied and the expression of COX-2 mRNA and protein were significantly inhibited.

Accumulating evidence has indicated that COX-2 promotes tumor growth, increases cancer cell invasiveness 
and metastasis through its catalytic activity $[35,36]$. Not only COX-2 transfection but also PGE2 treatment enhances cell migration and invasion in various types of human cancers [37-41]. In the present study, the invasion and migration ability of the SaOS2 cells were tested and found that COX-2 gene knockdown by RNAi resulted in a decreased level of invasion and migration. Therefore, there is a strong relationship between COX-2 and the invasion or migration ability of human osteosarcoma cells.

It is well known that the growth of tumor cells depends on nutrition supply, which largely relies on angiogenesis. VEGF plays a key role in normal and abnormal angiogenesis since it stimulates almost every step in the angiogenic process $[42,43]$. Other factors that have been shown to stimulate angiogenesis include EGF, bFGF, hepatocyte growth factor, interleukin-8, and placental growth factor $[44,45]$. Previous work indicated that COX-2 inhibitors blocked tumor growth via an antiangiogenic mechanism [46]. Moreover, studies demonstrated that there is a strong link between COX-2 expression and tumor angiogenesis [47]. Therefore, COX-2 overexpression may increase tumor blood supply and contribute to tumor growth. Our results suggest that knockdown of the COX-2 gene could suppress invasion and migration ability based on the down-regulation of $v e g f a$, egf and $b f g f$ expression in osteosarcoma cells.

\section{Conclusions}

Our experimental data demonstrate that RNAi-mediated downregulation of COX-2 effectively inhibited the cell proliferation, reduced invasion and migration ability of SaOS2 cells with the decreased expression of VEGFA, EGF and bFGF. Although the mechanism of this inhibition needs to be further investigated, our results suggest that COX-2 may have a role in angiogenesis and may be a potential therapeutic target for the treatment of human osteosarcoma.

\section{Acknowledgements \\ This research was supported by grants from the Shanghai Health Bureau Science Fund for Young Scholars (2009Y037), the Technology Development Fundation of Shanghai Jiaotong University School of Medicine (09XJ21048).}

\section{Author details}

${ }^{1}$ Department of Orthopaedics, Affiliated First People's Hospital, Shanghai Jiao Tong University, 100 Haining Road, Shanghai 200080, China. ²Department of Physical Examination, Affiliated First People's Hospital, Shanghai Jiao Tong University, 100 Haining Road, Shanghai 200080, China.

\section{Authors' contributions}

The authors contributed to this study as follows: QHZ and JWT designed the study;

QHZ, CW and JXZ performed experiments; LW analyzed data; SHD prepared the figures; JWT and GQZ drafted the manuscript. All authors have read and approved the final manuscript.

\section{Competing interests}

The authors declare that they have no competing interests.
Received: 14 January 2011 Accepted: 5 March 2011

Published: 5 March 2011

\section{References}

1. Bacci G, Longhi A, Versari M, Mercuri M, Briccoli A, Picci P: Prognostic factors for osteosarcoma of the extremity treated with neoadjuvant chemotherapy: 15-year experience in 789 patients treated at a single institution. Cancer 2006, 106:1154-1161.

2. Naruse T, Nishida Y, Hosono K, Ishiguro N: Meloxicam inhibits osteosarcoma growth, invasiveness and metastasis by COX-2-dependent and independent routes. Carcinogenesis 2006, 27:584-592.

3. Mirabello L, Troisi RJ, Savage SA: Osteosarcoma incidence and survival rates from 1973 to 2004: data from the Surveillance, Epidemiology, and End Results Program. Cancer 2009, 115:1531-1543

4. Longhi A, Errani C, De Paolis M, Mercuri M, Bacci G: Primary bone osteosarcoma in the pediatric age: State of the art. Cancer Treatment Reviews 2006, 32:423-436.

5. Yang G, Huang C, Cao J, Huang KJ, Jiang T, Qiu ZJ: Lentivirus-mediated shRNA interference targeting STAT3 inhibits human pancreatic cancer cell invasion. World J Gastroenterol 2009, 15:3757-3766.

6. Brown JR, DuBois RN: COX-2: a molecular target for colorectal cancer prevention. J Clin Oncol 2005, 23:2840-2855.

7. Strillacci A, Griffoni C, Valerii MC, Lazzarini G, Tomasi V, Spisni E: RNAi-based strategies for cyclooxygenase-2 inhibition in cancer. J Biomed Biotechnol 2010, 2010:828045

8. Denkert C, Kobel M, Berger S, Siegert A, Leclere A, Trefzer U: Expression of cyclooxygenase 2 in human malignant melanoma. Cancer Research 2001, 61:303-308.

9. Masferrer JL, Leahy KM, Koki AT, Zweifel BS, Settle SL, Woerner BM: Antiangiogenic and antitumor activities of cyclooxygenase-2 inhibitors. Cancer Res 2000, 60:1306-1311.

10. Kulkarni S, Rader JS, Zhang F, Liapis H, Koki AT, Masferrer JL: Cyclooxygenase-2 is overexpressed in human cervical cancer. Clinical Cancer Research 2001, 7:429-434.

11. Kokawa A, Kondo H, Gotoda T, Ono H, Saito D, Nakadaira S: Increased expression of cyclooxygenase-2 in human pancreatic neoplasms and potential for chemoprevention by cyclooxygenase inhibitors. Cancer 2001, 91:333-338.

12. Tsujii M, Kawano S, Tsuji S, Sawaoka H, Hori M, DuBois RN: Cyclooxygenase regulates angiogenesis induced by colon cancer cells. Cell 1998, 93:705-716.

13. Sawaoka H, Kawano S, Tsuji S, Tsujii M, Gunawan ES, Takei Y: Cyclooxygenase-2 inhibitors suppress the growth of gastric cancer xenografts via induction of apoptosis in nude mice. Am J Physiol 1998, 274:G1061-1067

14. Khuri FR, Wu H, Lee JJ, Kemp BL, Lotan R, Lippman SM: Cyclooxygenase-2 overexpression is a marker of poor prognosis in stage I non-small cell lung cancer. Clinical Cancer Research 2001, 7:861-867.

15. Xu Z, Choudhary S, Voznesensky O, Mehrotra M, Woodard M, Hansen M: Overexpression of COX-2 in human osteosarcoma cells decreases proliferation and increases apoptosis. Cancer Res 2006, 66:6657-6664.

16. Klein RD, Van Pelt CS, Sabichi AL, Dela Cerda J, Fischer SM, Furstenberger G Transitional cell hyperplasia and carcinomas in urinary bladders of transgenic mice with keratin 5 promoter-driven cyclooxygenase- 2 overexpression. Cancer Res 2005, 65:1808-1813.

17. Thun MJ, Henley SJ, Patrono C: Nonsteroidal anti-inflammatory drugs as anticancer agents: mechanistic, pharmacologic, and clinical issues. J Natl Cancer Inst 2002, 94:252-266.

18. Fosslien E: Biochemistry of cyclooxygenase (COX)-2 inhibitors and molecular pathology of COX-2 in neoplasia. Crit Rev Clin Lab Sci 2000, 37:431-502.

19. Wang R, Wang $X$, Lin F, Gao P, Dong K, Zhang HZ: shRNA-targeted cyclooxygenase (COX)-2 inhibits proliferation, reduces invasion and enhances chemosensitivity in laryngeal carcinoma cells. Mol Cell Biochem 2008, 317:179-188.

20. Fujita H, Koshida K, Keller ET, Takahashi Y, Yoshimito T, Namiki M: Cyclooxygenase-2 promotes prostate cancer progression. Prostate 2002, 53:232-240.

21. Klimp AH, Hollema $H$, Kempinga $C$, van der Zee $A G$, de Vries EG, Daemen $T$ : Expression of cyclooxygenase-2 and inducible nitric oxide synthase in 
human ovarian tumors and tumor-associated macrophages. Cancer Res 2001, 61:7305-7309.

22. Hida T, Yatabe Y, Achiwa H, Muramatsu H, Kozaki K, Nakamura S: Increased expression of cyclooxygenase 2 occurs frequently in human lung cancers, specifically in adenocarcinomas. Cancer Res 1998, 58:3761-3764.

23. Hwang D, Scollard D, Byrne J, Levine E: Expression of cyclooxygenase-1 and cyclooxygenase-2 in human breast cancer. J Natl Cancer Inst 1998, 90:455-460.

24. Attiga FA, Fernandez PM, Weeraratna AT, Manyak MJ, Patierno SR: Inhibitors of prostaglandin synthesis inhibit human prostate tumor cell invasiveness and reduce the release of matrix metalloproteinases. Cancer Res 2000, 4629-4637, 2000/09/02 ed.

25. Tsujii M, DuBois RN: Alterations in cellular adhesion and apoptosis in epithelial cells overexpressing prostaglandin endoperoxide synthase 2 . Cell 1995, 83:493-501.

26. Fujita T, Matsui M, Takaku K, Uetake H, Ichikawa W, Taketo MM: Size- and invasion-dependent increase in cyclooxygenase 2 levels in human colorectal carcinomas. Cancer Res 1998, 58:4823-4826.

27. Dandekar DS, Lokeshwar BL: Inhibition of cyclooxygenase (COX)-2 expression by Tet-inducible COX-2 antisense CDNA in hormonerefractory prostate cancer significantly slows tumor growth and improves efficacy of chemotherapeutic drugs. Clin Cancer Res 2004, 10:8037-8047.

28. Saikawa Y, Sugiura T, Toriumi F, Kubota T, Suganuma K, Isshiki S: Cyclooxygenase- 2 gene induction causes CDDP resistance in colon cancer cell line, HCT-15. Anticancer Res 2004, 24:2723-2728.

29. Chan MW, Wong CY, Cheng AS, Chan VY, Chan KK, To KF: Targeted inhibition of COX-2 expression by RNA interference suppresses tumor growth and potentiates chemosensitivity to cisplatin in human gastric cancer cells. Oncol Rep 2007, 18:1557-1562.

30. Larkins TL, Nowell M, Singh S, Sanford GL: Inhibition of cyclooxygenase-2 decreases breast cancer cell motility, invasion and matrix metalloproteinase expression. BMC Cancer 2006, 6:181.

31. van Wijngaarden J, van Beek E, van Rossum G, van der Bent C, Hoekman $K$, van der Pluijm G: Celecoxib enhances doxorubicin-induced cytotoxicity in MDA-MB231 cells by NF-kappaB-mediated increase of intracellular doxorubicin accumulation. Eur J Cancer 2007, 43:433-442.

32. Banu N, Buda A, Chell S, Elder D, Moorghen M, Paraskeva C: Inhibition of COX-2 with NS-398 decreases colon cancer cell motility through blocking epidermal growth factor receptor transactivation: possibilities for combination therapy. Cell Proliferation 2007, 40:768-779.

33. Zamore PD: RNA interference: listening to the sound of silence. Nat Struct Biol 2001, 8:746-750.

34. Gomase VS, Tagore S: RNAi-a tool for target finding in new drug development. Curr Drug Metab 2008, 9:241-244.

35. Lee EJ, Choi EM, Kim SR, Park JH, Kim H, Ha KS: Cyclooxygenase-2 promotes cell proliferation, migration and invasion in U2OS human osteosarcoma cells. Exp Mol Med 2007, 39:469-476.

36. Minter HA, Eveson JW, Huntley S, Elder DJ, Hague A: The cyclooxygenase 2-selective inhibitor NS398 inhibits proliferation of oral carcinoma cell lines by mechanisms dependent and independent of reduced prostaglandin E2 synthesis. Clin Cancer Res 2003, 9:1885-1897.

37. Tsujii M, Kawano S, DuBois RN: Cyclooxygenase-2 expression in human colon cancer cells increases metastatic potential. Proc Natl Acad Sci USA 1997, 94:3336-3340.

38. Sheng H, Shao J, Washington MK, DuBois RN: Prostaglandin E2 increases growth and motility of colorectal carcinoma cells. J Biol Chem 2001, 276:18075-18081.

39. Li G, Yang T, Yan J: Cyclooxygenase-2 increased the angiogenic and metastatic potential of tumor cells. Biochem Biophys Res Commun 2002, 299:886-890.

40. Han C, Wu T: Cyclooxygenase-2-derived prostaglandin E2 promotes human cholangiocarcinoma cell growth and invasion through EP1 receptor-mediated activation of the epidermal growth factor receptor and Akt. J Biol Chem 2005, 280:24053-24063.

41. Singh B, Berry JA, Shoher A, Ramakrishnan V, Lucci A: COX-2 overexpression increases motility and invasion of breast cancer cells. Int J Oncol 2005, 26:1393-1399.

42. Folkman J: Angiogenesis-dependent diseases. Semin Oncol 2001 28:536-542.
43. Liekens S, De Clercq E, Neyts J: Angiogenesis: regulators and clinical applications. Biochem Pharmacol 2001, 61:253-270.

44. Bellamy WT, Richter L, Sirjani D, Roxas C, Glinsmann-Gibson B, Frutiger Y: Vascular endothelial cell growth factor is an autocrine promoter of abnormal localized immature myeloid precursors and leukemia progenitor formation in myelodysplastic syndromes. Blood 2001, 97:1427-1434.

45. Yoshida S, Ono M, Shono T, Izumi H, Ishibashi T, Suzuki H: Involvement of interleukin-8, vascular endothelial growth factor, and basic fibroblast growth factor in tumor necrosis factor alpha-dependent angiogenesis. Mol Cell Biol 1997, 17:4015-4023.

46. Leahy KM, Ornberg RL, Wang Y, Zweifel BS, Koki AT, Masferrer JL: Cyclooxygenase- 2 inhibition by celecoxib reduces proliferation and induces apoptosis in angiogenic endothelial cells in vivo. Cancer Res 2002, 62:625-631.

47. Macpherson GR, Ng SSW, Lakhani NJ, Price DK, Venitz J, Figg WD: Antiangiogenesis therapeutic strategies in prostate cancer. Cancer and Metastasis Reviews 2002, 21:93-106.

doi:10.1186/1756-9966-30-26

Cite this article as: Zhao et al: RNAi-mediated knockdown of cyclooxygenase 2 inhibits the growth, invasion and migration of SaOS2 human osteosarcoma cells: a case control study. Journal of Experimental \& Clinical Cancer Research 2011 30:26.

\section{Submit your next manuscript to BioMed Central and take full advantage of:}

- Convenient online submission

- Thorough peer review

- No space constraints or color figure charges

- Immediate publication on acceptance

- Inclusion in PubMed, CAS, Scopus and Google Scholar

- Research which is freely available for redistribution

Submit your manuscript at www.biomedcentral.com/submit
C Biomed Central 